\title{
Preliminary recognition of state of incorporating climate change impacts and adaptation considerations in SEA and EIA procedures for renewable energy projects
}

\author{
Magdalena Tyszer ${ }^{1, *}$, and Slávka Gałaś ${ }^{1}$ \\ ${ }^{1}$ AGH University of Science and Technology in Kraków, Faculty of Geology, Geophysics and \\ Environmental Protection, al. Mickiewicza 30, 30-059 Kraków, Poland
}

\begin{abstract}
In the last years, the European Union has developed and set a several environmental policies whose imposes an obligation on Member States to implement specific actions, including incorporating climate change considerations into SEA and EIA processes. One of major environmental challenges facing most developing countries is that of global climate change. The aim of the research was to obtain a comprehensive review of existing SEA and EIA practical approaches for renewable energy installations in the aspect of adaptation to climate change with specific reference to Polish projects. Both SEA and EIA procedures implemented in Poland and other countries was introduced with the intent of factoring in potential risk to the environment by future large-scale project developments such as the construction of power plants, roads, or dams. The paper consist the initial recognition of available data of the current experience and level of implementation climate change impact and adaptions into local procedures. Preliminary results suggest that the additional funding should be given for climate change adaptation in the energy sector, especially in renewable energy projects, as well as specific interventions for climate-adapted energy systems should be targeted in order to fill the gap in RES sector and spur sustainable energy development.
\end{abstract}

\section{Introduction}

In last years, both the dynamic growth of the population, the use of natural resources and, consequently, the increase in demand for energy and fresh water have led to the search for new sources of energy and water, primarily from renewable energy sources. Furthermore, knowing the fact that in the terms of distribution of water resources on Earth, nearly $97.5 \%$ are highly saline oceanic waters directly unsuitable for consumption and also dramatically declining freshwater resources force countries to invest in new ways of obtaining and processing products previously considered as waste [1]. Consideration of global warming and its changes in relation to large-scale projects for which environmental

* Corresponding author: mtyszer@agh.edu.pl 
impact assessments are required is increasingly common and emphasised in global publications. The European Union, through the introduction of specific Directives, forces Member States to take specific measures to protect the environment and points out that climate change is currently one of the most important challenges not only for the community, but also for the whole world [2]. One of the most important tools that can be used by countries to protect the environment are Strategic Environmental Assessment (SEA) and Environmental impact assessment (EIA) [3]. Strategic Environmental Assessment (SEA), as procedural decision support technique that in prior decision-making process evaluates environmental policies, plans and programs in order to protect natural capital and to develop sustainable and efficient green economy, should be enriched with climate change impacts and its adaptation [4]. Environmental Impact Assessment (EIA), as the first tool in broadly understood recognition of environmental, social and economic impacts of the planned project, including large-scale renewable energy installations (LS$\mathrm{RE}$ ), on the environment, prior to decision-making process, should consider climate changes consequences and indicate appropriate protecting method [5 - 7]. Considering the cataclysmic effects that intensifying anthropogenic climate change and global warming have on the world's ecosystems and given the fact that fossil-fuel related greenhouse gases (GHG) represent the main drivers, finding ways how to reduce said negative externalities has become one of the major challenges for humanity [8]. The purpose of this paper is to analyse a current state of implementation climate change impacts and adaptation considerations in SEA and EIA procedures for large-scale renewable energy installations based on selected examples.

\section{Current state of implementation climate change impacts and adaptation considerations in SEA and EIA procedures for renewable energy projects}

In the view of climate crisis and dwindling stocks of conventional fuels the importance and urgency of incorporating climate change considerations into EIA processes is underlined in political discussions. The European Union Member States are forced to take it into account by the recent revision of the EU Directive 2014/52/EU on Environmental Impact Assessment changes in EIA practice [2]. Climate change impacts and adaptation in EIA projects are not specified yet and in different countries are introduced in their own way. Jiricka et al. [2] suggested categorization of climate change-related as: 1) direct impacts of climate change projects, 2) indirect impacts on projects (associated with environment), and 3) changes of impacts on the environment by projects caused by an increased vulnerability of environmental issues. Tolli et al. [3] also indicate the importance of the assessment of aesthetic and perceptual aspects within EIA of LS-RE projects on the example of Italy. Loomis and Dziedzic [5] investigate the level of effectiveness of EIA systems based on literature data and information. Other researches also point to the need for changes in the EIA or present the current state of climate change impact implementation.

\subsection{Desalination plant project - EIA procedures on the example of Taiwan}

Seawater desalination plants are increasingly being built in different parts of the world due to dwindling drinking water supplies and the need for large quantities of water for the agricultural sector. The method of environmental impact assessment of this type of investment will be presented on the basis of an example from Taiwan. The 12 EIA commissioners were interviewed to assess the environmental impact of the planned project of sweater desalination installation in Taiwan. As a result of the analysis of the replies 
received, a table was drawn up which sets out the factors and their weightings as indicated by the Commissioners. Table 1 presents the weights of four environmental impact dimentions (physical and chemical environmental, ecological, economic, and society dimention). The most important was established as ecological - almost $37 \%$, followed by society - almost $30 \%$, economic - more than $23 \%$, and physical $/$ chemical environmental dimention - more than $9 \%$ (Table 1) [1].

Table 1. The weight of the established four dimentions by EIA commissioners [1].

\begin{tabular}{|c|c|c|c|c|}
\hline First level (goal) & Second level (dimention) & Third level (evaluation factor) & Weight in each dimension & Weight \\
\hline \multirow{17}{*}{ Environmental impact from desalination plant } & Physical and chemical environment dimension & Noise, vibration, and solid waste & 24.796 & $2.4 \%$ \\
\hline & & Topographic geology and soil & $14.9 \%$ & $1.4 \%$ \\
\hline & & Hydrology and water quality & $41.8 \%$ & $4.1 \%$ \\
\hline & & Weather and air quality & $18.6 \%$ & \\
\hline & & Subtotal & & \\
\hline & Ecological Dimension & Territorial ecology & $13.0 \%$ & 4.896 \\
\hline & & Marine ecology & $45.5 \%$ & $16.8 \%$ \\
\hline & & $\begin{array}{l}\text { Ecosystem and species conservation } \\
\text { Subtotal }\end{array}$ & $\begin{array}{l}41.5 \% \\
100 \%\end{array}$ & $\begin{array}{l}15.396 \\
36.996\end{array}$ \\
\hline & Economic dimension & Traffic and transportation & $8.1 \%$ & $1.9 \%$ \\
\hline & & Energy & $35.5 \%$ & $8.4 \%$ \\
\hline & & Fishery resources & $41.8 \%$ & $9.9 \%$ \\
\hline & & Scenic resources and recreation & $14.6 \%$ & $3.5 \%$ \\
\hline & & Subtotal & $100 \%$ & $23.7 \%$ \\
\hline & Society dimension & Land and ocean utilisation & $28.9 \%$ & $8.6 \%$ \\
\hline & & Social environment & $26.5 \%$ & 7.996 \\
\hline & & Social relationships & $18.9 \%$ & $5.6 \%$ \\
\hline & & $\begin{array}{l}\text { Cultural resources } \\
\text { Subtotal }\end{array}$ & $\begin{array}{l}25.6 \% 6 \\
100 \%\end{array}$ & $\begin{array}{l}7.6 \% 6 \\
29.7 \%\end{array}$ \\
\hline
\end{tabular}

Major concern about this installation was established as possible degradation of the marine ecological environment, climate change related factors were not taken into account in this analysis.

\subsection{Approval procedures for large-scale renewable energy installations: Comparison of national legal frameworks in Japan, New Zealand, the EU and the USA}

Due to different ways of conducting environmental impact assessments and the degree of implementation of climate change considerations, Schumacher presented a summary of the procedures applied in New Zealand, Japan, the USA and the EU [7]. The aim of the Schumacher study was to examine the role of EIA procedures, which are mandatory for LS$\mathrm{RE}$ installations and which at the same time hamper the development of these projects. In Table 2 is presented the state of implementation of the RE installation in total energy production [7].

Table 2. The percentage share of RE installations in total energy production [7].

\begin{tabular}{lllllr}
\hline Country/region & TPES (2016) & TPES (2016; Share fossil fuels) & NDC GHG reductions & RE target share & RE share current \\
\hline Japan & 424 Mtoe $^{-}$ & $93.6 \%$ & $26 \%$ by 2030 (base year 2013) & $22-24 \%$ by 2030 & $4.8 \%$ \\
New Zealand & 21 Mtoe & $59.3 \%$ & $30 \%$ by 2030 (base year 2005) & $100 \%$ by 2035 & $40.5 \%$ \\
EU & 1717 Mtoe & 71.9 & $40 \%$ by 2030 (base year 1990) & $27 \%$ by 2030 & $14.2 \%$ \\
US & 2159 Mtoe & 82.3 & $26-28 \%$ by 2025 (base year 2005) & Currently no fixed political target. & $7.1 \%$ \\
\hline
\end{tabular}

As can be seen from Table 2, the highest percentage of installations based on conventional energy sources was found for Japan, which is $93.6 \%$. The largest planned share of RE installations was established for New Zealand, it is to be $100 \%$ by 2035 [7]. Subsequently, the analysis presented indicates the main existing legal acts related to EIA procedures, which are set out in Table 3.

Table 3. Main existing legal acts related to EIA procedures in Japan, New Zealand, EU and US [7].

\begin{tabular}{|c|c|c|c|}
\hline Japan & New Zealand & EU & us \\
\hline $\begin{array}{l}\text { - Basic Environment Law } 1993 \\
\text { Environmental Impact Assessment Law } 1997 \\
\text { Environmental Impact Assessment Law } \\
\text { - Prendment } 2011 \\
\text { Prefectural and municipal ordinances }\end{array}$ & $\begin{array}{l}\text { - Resources Management Act } 1993 \\
\text { - Resources Management Amendment } \\
\text { - Act } 2009 \\
\text { Environmental Protection Authority } \\
\text { - Act } 2011 \\
\text { Resources Management Amendment } \\
\text { Act } 2013\end{array}$ & $\begin{array}{l}\text { - EIA Directive 2011/92/EU } \\
\text { EIA Directive 2014/52/EU } \\
\text { - TEN-E Regulation No. 347/ } \\
2013 \\
\text { - Birds Directive 2009/147/ } \\
\text { EC } \\
\text { - Habitats Directive 92/43/ } \\
\text { EEC }\end{array}$ & $\begin{array}{l}\text { - National Environmental Protection Act } \\
1970 \\
\text { - Clean Air Protection Act } 1970 \\
\text { - Bald and Golden Eagle Protection Act } \\
1940 \\
\text { - Migratory Bird Treaty Act } 1918 \\
\text { - Endangered Species Act } 1973 \\
\text { - State-level Environmental Protection } \\
\text { Action Acts }\end{array}$ \\
\hline
\end{tabular}

On the basis of Table 3 we can observe that most legal acts have not been updated for even a dozen or so years. Consequently, most legislation does not take into account 
considerations related to climate change and its implementation in procedures. However, in each of the analysed areas, both strengths and weaknesses of legal regulations were identified (Tables 4 and 5) [7].

Table 4. Main advantages of the regulatory framework for EIA procedures [7].

\begin{tabular}{|c|c|c|c|}
\hline Japan & New Zealand & EU & us \\
\hline $\begin{array}{l}\text { (+) High degree of public and local } \\
\text { involvement }\end{array}$ & $\begin{array}{l}(+) \text { Extremely short processing timeframes } \\
\text { between application and final decision } \\
\text { under the EPA approval process }\end{array}$ & $\begin{array}{l}(+) \text { Increased public input (minimum } \\
\text { public consultation period) }\end{array}$ & $\begin{array}{l}(+) \text { Federal process only for projects } \\
\text { with federal involvement (most RE } \\
\text { projects excluded) }\end{array}$ \\
\hline $\begin{array}{l}(+) \text { Many stages for revisions and } \\
\text { subsequent input }\end{array}$ & $\begin{array}{l}(+) \text { Cost limits and fixed maximum } \\
\text { timeframes for PNSs ( } 9 \text { months total) and } \\
\text { medium-sized regular AEEs ( } 6 \text { months) }\end{array}$ & $\begin{array}{l}(+) \text { Creation of harmonised guidelines } \\
\text { and increased screening process } \\
\text { clarifications }\end{array}$ & $\begin{array}{l}\text { (+) Some states without any } \\
\text { environmental approval regulations } \\
=\text { Short duration and cost }\end{array}$ \\
\hline $\begin{array}{l}\text { (+) Implementation of restructuring plans } \\
\text { for } \mathrm{RE} \text { installations }\end{array}$ & $\begin{array}{l}(+) \text { Cost support for surveys and pre-EIA } \\
\text { steps in some instances }\end{array}$ & $\begin{array}{l}(+) \text { More clarity through increased } \\
\text { public accountability, monitoring and } \\
\text { expert involvement }\end{array}$ & $\begin{array}{l}(+) \text { High level of public involvement } \\
\text { and mandatory timeframes (under } \\
\text { NEPA) }\end{array}$ \\
\hline $\begin{array}{l}\text { (+) High degree of accountability, pre- } \\
\text { and post-monitoring provisions }\end{array}$ & $(+)$ Integrated one-stop shop approach & $\begin{array}{l}(+) \text { Creation of one-stop shop } \\
\text { requirement for EIN/Birds/Habitats } \\
\text { (Natura2000) Directives }\end{array}$ & \\
\hline $\begin{array}{l}\text { (+) For national ELAs, high degree of } \\
\text { shared expertise between MOE and } \\
\text { METI }\end{array}$ & $(+)$ Limited legal obstruction possibilities & & \\
\hline
\end{tabular}

Table 5. Main drawbacks of the regulatory framework for EIA procedures [7].

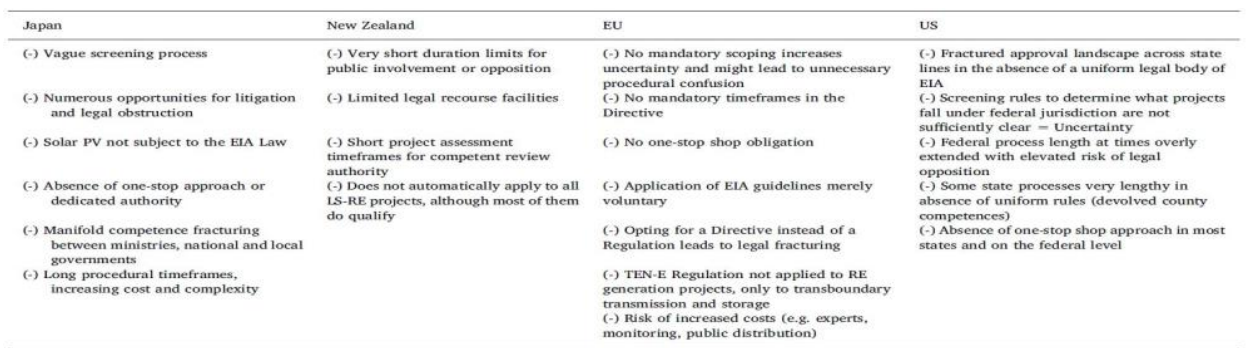

On the basis of the above tables can be observe that in both the EU and Japan the advantage is high public participation and awareness, whereas in New Zealand and the US the short time and easy way of process of the EIA procedure. On the other hand, visible drawbacks of the process of implementing EIA procedures in particular areas are unclear rules for some projects, including RES, and the inability to abolish the obligation to implement the EIA procedure for them, as well as the absence of consideration of climate change and its consequences [7].

\subsection{SEA and EIA procedures in Poland}

Poland adjust its law to EU standards provided for EIA in order to meet the standards established by EU Directive (Directive 2014/52/EU) [4, 9]. The legal acts defining the competences of the General Director for Environmental Protection in Poland, who is responsible for the EIA and SEA procedures, are as follows: 1) the Act of 3 October 2008 on sharing information about the environment and its protection, public participation in environmental protection and environmental impact assessment, 2) the Act of 27 April 2001. Environmental Law (Journal of Laws of 2017, item 519, as amended), 3) the Act of 16 April 2004 on the Nature Conservation (Journal of Laws of 2018, item 1614), 4) the Act of 13 April 2007 on preventing the damages to nature and their compensation (Journal of Laws of 2014, item 1789, as amended), and 5) the Act of July 15, 2011 on the National Community Eco-management and Audit Scheme (EMAS) (Journal od Laws, item. 1060). Moreover, concerning EIA procedures, the following implementing act should also be mentioned - Regulation of the Council of Ministers of 9 November 2010 on projects likely to have significant effects on the environment (Journal of Laws of 2016, item 71). On the basis of Polish law, more specifically, on the basis of regulation of the Council of Ministers of 9 November 2010 on types of projects likely to have significant effects on the environment (Journal of Laws No. 213, item 1397, as amended) [10] projects are divided into two basis categories: 1) projects, which can always significantly affect the 
environment, and 2) projects, which can potentially significantly affect the environment. For the first one, the EIA procedure is mandatory, whereas for the second one the need for assessing the environmental impact is stated by the authority mentioned in the Act of 3 October 2008 on sharing information about the environment and its protection, public participation in environmental protection and environmental impact assessment. With reference to the above regulation, some installations using renewable energy sources are classified as projects which may always have a significant impact on the environment and may potentially have a significant impact on the environment. In the first case, this may apply: 1) agricultural biogas plants - installations for the manufacture of substances using chemical products to produce basic products or semi-finished products of organic and inorganic chemistry, 2) wind power plants - installations using wind energy for the generation of electricity with the total nominal power of not less than $100 \mathrm{MW}$ and located in maritime areas of Poland (excluding power plants with the height of less than $30 \mathrm{~m}$ ), 3) water damming structures - installations with the height of not less than $5 \mathrm{~m}$, and 5) dams installations intended for the retention and permanent retention of not less than 10 million $\mathrm{m}^{3}$ of water mass. The second category may include the following RES installations: 1) hydroelectric power stations, 2) other installations using wind energy for electricity generation, which are located in areas covered by forms of nature protection and with a total height of not less than $30 \mathrm{~m}, 3$ ) installations for the production of fuel from plant products excluding agricultural biogas installations with an installed electrical capacity of $0.5 \mathrm{MW}$ or less or with an equivalent amount of agricultural biogas produced for purposes other than electricity production, 4) industrial or storage buildings with accompanying infrastructure with a building area of not less than 0.5 ha in the areas covered by nature protection forms or in the buffer zones of nature protection forms, and 5) other water damming systems located in the areas covered by the forms of nature protection with the exception of structures damming water to a height of less than $1 \mathrm{~m}[11,12]$. Of course, we also need to pay attention to other legal regulations applicable in Poland that condition and determine the rules for the execution of installations using renewable energy sources, such as the Act of 20 May 2016 on investments in wind power plants, the Act of 9 June 2011 Geological and Mining Law (primarily concerning geothermal installations) and others, which concern particular RES installation. As in other countries, in Poland, according to the applicable regulations, for most LS-RE installations it is necessary to perform the EIA procedure, which may significantly delay or even inhibit the execution of a key investment due to dwindling water resources or climatic changes threatening the natural environment. It is important to lay down clear rules at legislative level for carrying out EIA procedures for LS-RE installations in order to enable the dynamic development of this industry. The first approved strategic document to address adaptation to climate change is the Strategic Adaptation Plan for sectors and areas sensitive to climate change by 2020 with a 2030 perspective, the so-called SPA2020. It is a framework document containing directional guidelines on adaptation to climate change for EU Member States and regions. Its main objectives are: raising awareness on the importance of adaptation, exchange of information, cooperation and partnership, integrated approach - integration of adaptation issues into other policies, national and regional/local dimension of adaptation (SPA 2020 and voivodeship development strategies/complex urban adaptation plans). In SPA 2020 there were proposed actions particularly important to be carried out in the voivodships. These actions include, for example, flood protection or the creation of early warning systems against flood risks. In Poland, the Ministry of the Environment ensures an effective flow of information and good practices between institutions involved in the implementation of SPA 2020, in particular by setting up an informal network cooperation in the field of adaptation and developing the KLIMADA portal (a modern portal containing all information on climate change and adaptation to climate change). However, despite measures aimed at 
adaptation for sectors and areas sensitive to climate change (SPA 2020), in Poland most legal acts do not take into account (or to a small extent) these conditions, even in the case of EIA for LS-RE.

\section{Conclusions}

Future energy policy research should determine if the conceptual approaches of these reforms lead to increased RE growth and stakeholder satisfaction. EIA frameworks for LSRE projects need to be conceptualised and structured with a balance between environmental protection, economic viability and public concerns in mind to underpin the core aspects of energy justice. Despite this being considered as an important step in raising environmental awareness and protecting natural resources this procedures are also required for large-scale renewable energy projects and are considered as barriers in theirs development. Preliminary results suggest that the additional funding should be given for climate change adaptation in the energy sector, especially in renewable energy projects, as well as specific interventions for climate-adapted energy systems should be targeted in order to fill the gap in RES sector and spur sustainable energy development. The EIA procedures themselves should also be adapted to LS-RE and climate change to allow for a percentage increase in the energy generated by RES installations.

The project is co-financed by the Polish National Agency for Academic Exchange (PPN/BIL/2018/1/00062).

\section{References}

1. T.-K. Liu, T.-H. Weng, H.-Y. Sheu, Desalination 428 (2018)

2. A. Jiricka, H. Formayer, A. Schmidt, S. Voller, M. Leitner. T.B. Fischer, T.F. Wachter, Environ. Impact Asses. 57 (2016)

3. M. Tolli, F. Recanatesi, M. Piccinno, A. Leone, Environ. Impact Asses. 57 (2016)

4. S. Gałaś, A. Gałaś, M. Zelenakowa, L. Zvijakova, J. Fialkova, H. Kubickova, Environ. Impact Asses. 55 (2015)

5. J.J. Loomis, M. Dziedzic, Environ. Impact Asses. 68 (2018)

6. K. Schumacher, Environ. Impact Asses. 65 (2017)

7. K. Schumacher, Energ. Policy 129 (2019)

8. C. Lohse, Renew. Energ. 128 (2018)

9. Directive 2014/52/EU of the European Parliament and of the Council of 16 April 2014 amending Directive 2011/92/EU on the assessment of the effects of certain public and private projects on the environment

10. Regulation of the Council of Ministers of 9 November 2010 on types of projects likely to have significant effects on the environment (Journal of Laws No. 213, item 1397, as amended)

11. Law of 3.10 .2008 on the provision of information on the environment and its protection, public participation in the environmental protection and environmental impact assessments and its amendments (Journal of Laws No. 199, item 1227) in later wording (in Polish)

12. J. Borowski, M. Walas, Polish Yearbook of Environmental Law 6 (2016) http://dx.doi.org/10.12775/PYEL.2016.003 